\title{
The impact of ovulation on fallopian tube epithelial cells: evaluating three hypotheses connecting ovulation and serous ovarian cancer
}

\author{
Shelby M King, Tyvette S Hilliard, Lucia Y Wu, Randal C Jaffe ${ }^{1}$, \\ Asgerally T Fazleabas ${ }^{2}$ and Joanna E Burdette
}

\begin{abstract}
Department of Medicinal Chemistry and Pharmacognosy, University of Illinois at Chicago College of Pharmacy, $900 \mathrm{~S}$. Ashland, Chicago, Illinois 60612, USA

${ }^{1}$ Department of Physiology and Biophysics, University of Illinois at Chicago, $835 \mathrm{~S}$. Wolcott Avenue, Chicago, Illinois 60612, USA ${ }^{2}$ Department of Obstetrics, Gynecology, and Reproductive Biology, Michigan State University College of Human Medicine, 333 Bostwick Avenue NE, Grand Rapids, Michigan 49503, USA
\end{abstract}

(Correspondence should be addressed to J E Burdette; Email: joannab @ uic.edu)

\begin{abstract}
Ovarian cancer is the most lethal gynecological malignancy affecting American women. Current hypotheses concerning the etiology of ovarian cancer propose that a reduction in the lifetime number of ovulations decreases ovarian cancer risk. Advanced serous carcinoma shares several biomarkers with fallopian tube epithelial cells, suggesting that some forms of ovarian carcinoma may originate in the fallopian tube. Currently, the impact of ovulation on the tubal epithelium is unknown. In CD1 mice, ovulation did not increase tubal epithelial cell (TEC) proliferation as measured by bromodeoxyuridine incorporation and proliferating cell nuclear antigen staining as compared to unstimulated animals. In superovulated mice, an increase in the number of pro-inflammatory macrophages was detected in the oviduct. Ovulation also increased levels of phospho- $\gamma \mathrm{H} 2 \mathrm{~A} . \mathrm{X}$ in TEC, indicating that these cells were susceptible to double-strand DNA breakage following ovulation. To determine which components of ovulation contributed to DNA damage in the fallopian tube, an immortalized baboon TEC cell line and a three-dimensional organ culture system for mouse oviduct and baboon fallopian tubes were developed. TEC did not proliferate or display increased DNA damage in response to the gonadotropins or estradiol alone in vitro. Oxidative stress generated by treatment with hydrogen peroxide or macrophageconditioned medium increased DNA damage in TEC in culture. Ovulation may impact the fallopian tube epithelium by generating DNA damage and stimulating macrophage infiltration but does not increase proliferation through gonadotropin signaling.
\end{abstract}

Endocrine-Related Cancer (2011) 18 627-642

\section{Introduction}

Ovarian cancer is the most lethal gynecological malignancy and the fifth leading cause of cancer death among women, due in part to a lack of early detection methods (Jemal et al. 2009). As a result, $\sim 62 \%$ of ovarian cancers are not detected until after the tumors have metastasized, resulting in high mortality rates and few treatment options (Altekruse et al. 2010). The most common histotype of epithelial ovarian cancer is serous carcinoma, which has previously been reported to arise from precursor lesions involving the ovarian surface epithelium (OSE) or ovarian epithelial inclusion cysts (Scully 1995, Auersperg et al. 2002). Emerging evidence indicates that the fallopian tube epithelium may be an alternative site of origin for serous ovarian cancers (Bell 2005, Altekruse et al. 2010). A striking resemblance between the fallopian tube epithelium and serous ovarian cancer has been observed; this includes similar gene expression profiles, cell morphologies, and expression of E-cadherin, all of which are distinct from the OSE (Auersperg et al. 2008). 
Several lines of evidence support the fallopian tube as a source of neoplastic cells for the initiation of serous cancer. The majority of women with advanced stage serous cancer exhibit preneoplastic lesions in the fallopian tube in addition to a dominant ovarian mass (Jarboe et al. 2008b). A 'p53 signature' has been identified, which marks precursor lesions of the distal fallopian tube that are composed of morphologically benign epithelium exhibiting elevated levels of p53 protein expression (Lee et al. 2007). Identical p53 mutations have been observed in tumors of the distal fallopian tube and in ovarian or peritoneal serous carcinomas, suggesting a common source (Jarboe et al. 2008 a). Women with BRCA1 or BRCA2 mutations are more likely to exhibit expression of the p53 signature as well as primary fallopian tube carcinoma, indicating that an association may exist between the BRCA mutation phenotype and serous cancer originating from the fallopian tube (Cass et al. 2005). However, much is still unknown about the association between neoplastic lesions of the fallopian tube and development of serous pelvic or ovarian cancer, largely due to a lack of tools to model neoplasia in the fallopian tube. The laying hen has been used as an animal model for spontaneous ovarian and tubal cancer, and although these animals exhibit primarily the endometrioid histotype rather than the serous histotype of adenocarcinoma, a recent analysis depicted oviductal genes expressed at high levels in cancers as the grade increased (Hakim et al. 2009, Trevino et al. 2010). A human fallopian tube ex vivo culture system was developed, which allows for co-culture of both secretory and ciliated cells of the fallopian tube (Levanon et al. 2010). This represents significant improvements over previous tubal epithelial cell (TEC) culture systems but does not allow for analysis of TEC in the context of their physiological microenvironment in contact with stroma and extracellular matrix, or for any in vivo analysis of how ovulation might damage tubal cells.

Serous ovarian cancer is largely a spontaneous disease, although $\sim 10 \%$ of cases are linked to mutations in BRCA1 and BRCA2 (Crum et al. 2007a). Risk factors for spontaneous serous cancer include nulliparity, infertility, and an early onset of puberty or late menarche, while pregnancy, breastfeeding, and the use of oral contraceptives are protective against ovarian cancer (Auersperg et al. 2008). An increased incidence of non-familial, spontaneous ovarian cancer is linked to an increased number of lifetime ovulations, and several hypotheses have been proposed linking events associated with ovulation to ovarian cancer initiation and progression. The first hypothesis is Fathalla's tearand-repair hypothesis, which states that as a result of repetitive proliferation of the OSE to repair the ovulation-induced wound in the ovarian surface, spontaneous DNA replication errors accumulate, leading to neoplasia and ovarian cancer (Fathalla 1971). OSE have been shown to proliferate in response to ovulation and to exhibit signs of DNA damage (Murdoch et al. 2001, Burdette et al. 2006), but the effects of ovulation on TEC proliferation and DNA damage are unknown. The second hypothesis linking ovulation to ovarian cancer concerns the gonadotropins, FSH, and LH, which are thought to contribute to the initiation and progression of ovarian cancer by stimulating the growth of the OSE and/or inhibiting apoptosis of damaged cells (Konishi et al. 1999). Both the OSE and the TEC have been shown to express receptors for $\mathrm{FSH}, \mathrm{LH}$, and estradiol, though the exact role of these hormones in stimulating TEC in vivo is not known (Zheng et al. 1996, Zhang et al. 2001). The third hypothesis states that inflammation induced by ovulation may generate oxidative stress that is further exacerbated by cellular proliferation and the effects of FSH and LH, leading to DNA damage and replication errors. Ovulation generates inflammatory molecules such as bradykinin, prostaglandins, and leukotrienes through ischemia-reperfusion associated with wound repair, as well as through recruitment of leukocytes to sites of ovulation (Murdoch 2008). However, an association between ovulation and inflammation in TEC has not been examined.

The purpose of this study was to evaluate common hypotheses regarding ovulation and the initiation of serous epithelial cancer to determine how proliferation (tear and repair), the gonadotropins, and inflammatory molecules influence normal TEC. Following ovulation, TEC might possibly be sloughed onto the ovarian surface due to the close proximity of the distal fimbriae of the fallopian tube to the ovarian rupture site by a process similar to retrograde menstruation. Sloughed cells might form inclusion cysts in which the epithelial cells are exposed to increased levels of hormones and growth factors (Kurman \& Shih Ie 2010). The process of ovulation releases growth factors, steroid hormones, and inflammatory molecules, and the fallopian tube is in close proximity to the source of these factors. The current study reports that ovulation does not increase TEC proliferation in vivo. Moreover, using a novel organ culture system to study mouse TEC and baboon fimbriae TEC, as well as a newly generated immortalized baboon TEC cell line (TEC40), FSH and LH do not induce proliferation of TEC. TEC from ovulated animals exhibit increased levels of DNA damage and macrophage infiltration into the oviduct. Oxidative stress generated by hydrogen peroxide or 
macrophage-conditioned media increased DNA damage in TEC40.

\section{Materials and methods}

\section{Animals}

Day 25 female CD1 mice were used for in vivo ovulation studies. For organ culture experiments, mouse oviducts were isolated from CD1 day 16 female pups. All mice were acquired through in-house breeding, and breeders were purchased from Harlan (Indianapolis, IN, USA). Fimbriae tissue was obtained from adult female baboons (Papio anubis) housed at the University of Illinois at Chicago under the supervision of Dr Fazleabas. All animals were treated in accordance with the National Institutes of Health Guide for the Care and Use of Laboratory Animals and the established institutional animal use and care protocol at the University of Illinois at Chicago. Animals were housed in a temperature and lightcontrolled environment (12 h light: $12 \mathrm{~h}$ darkness) and were provided food and water ad libitum.

\section{Experimental design of ovulation study}

Induction of ovulation was performed essentially as described previously and in Fig. 1 (Burdette et al. 2006). Control mice were injected i.p. with PBS at $0900 \mathrm{~h}$ on $\mathrm{d} 25$ and $0900 \mathrm{~h}$ on $\mathrm{d} 27$. Ovulated mice were injected i.p. with $5 \mathrm{IU}$ pregnant mare serum gonadotropin (PMSG; Sigma-Aldrich) at $0900 \mathrm{~h}$ on d25 and 5 IU human chorionic gonadotropin (hCG; Sigma-Aldrich) at $0900 \mathrm{~h}$ on $\mathrm{d} 27$. Injections containing $100 \mathrm{mg} / \mathrm{kg}$ bromodeoxyuridine (BrdU; Sigma-Aldrich) were given i.p. either at the time of the first and second hormone or PBS injections or solely with the second injection. On first injection of BrdU, animals were given water containing $0.8 \mathrm{mg} / \mathrm{ml} \mathrm{BrdU}$ to allow for continuous labeling. At $2100 \mathrm{~h}$ on d27.5, animals were killed using $\mathrm{CO}_{2}$ asphyxiation and cervical dislocation. Total basal proliferation occurring over $60 \mathrm{~h}$ was assessed by injecting mice $(n=6)$ with PBS and $\mathrm{BrdU}$ at $0900 \mathrm{~h}$ on $\mathrm{d} 25$, followed by continuous labeling with BrdU until $2100 \mathrm{~h}$ on d27.5. Abridged basal proliferation was measured by injecting mice $(n=3)$ with PBS and BrdU at $0900 \mathrm{~h}$ on $\mathrm{d} 27$, with labeling until $2100 \mathrm{~h}$ on $\mathrm{d} 27.5$ for a labeling time of
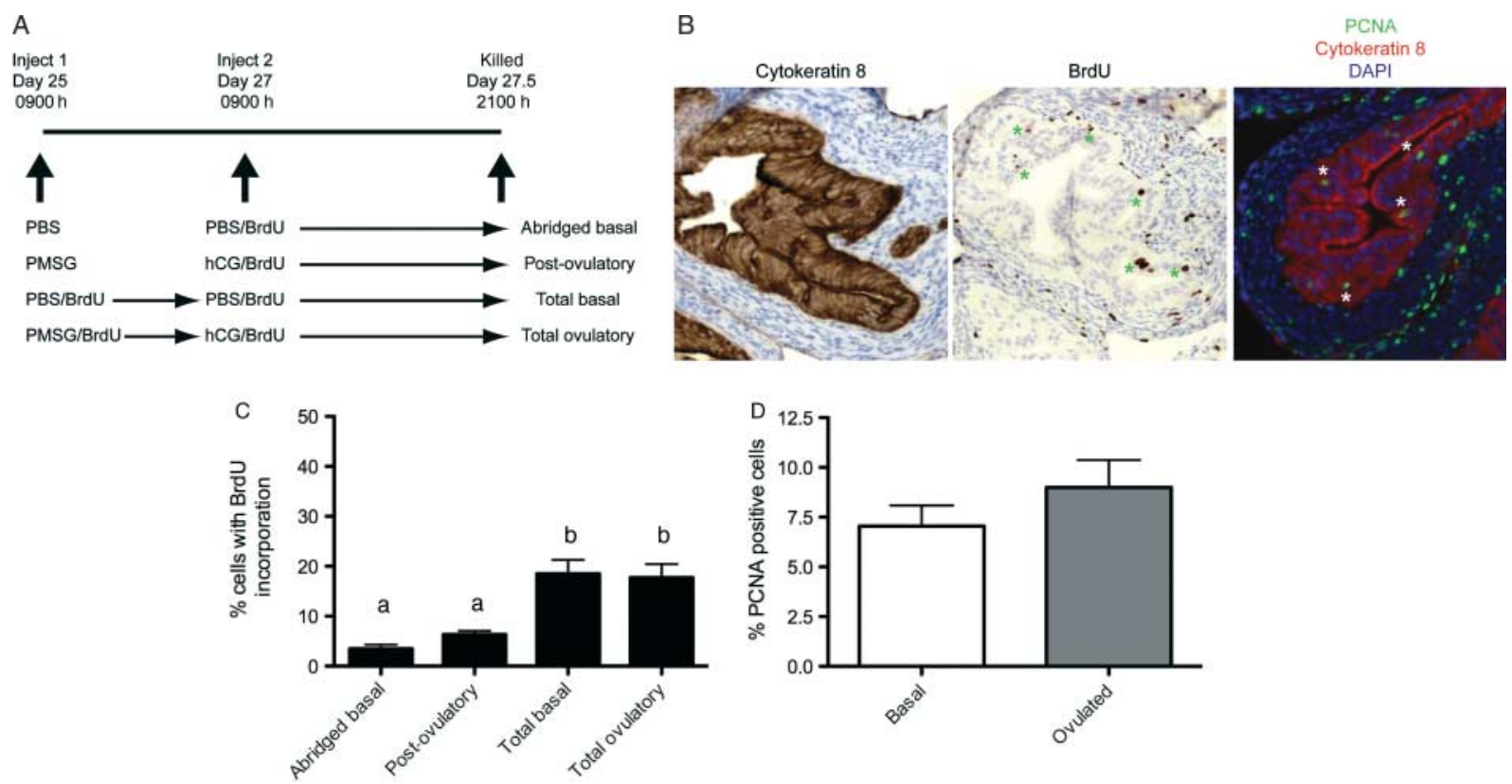

Figure 1 TECs do not proliferate in response to ovulation in vivo. (A) CD1 mice were injected with buffer (PBS) as a control or hormones (PMSG and hCG) to induce ovulation. BrdU was added to control injections on either day 25 or 27 to measure cellular proliferation during a $12 \mathrm{~h}$ (abridged basal) or $60 \mathrm{~h}$ (total basal) labeling period. Total cellular proliferation (total ovulatory) or proliferation in response to hCG stimulation and the process of ovarian surface rupture (post-ovulatory) was measured by adding BrdU to the d25 and d27 injections, respectively. (B) Oviductal sections $(5 \mu \mathrm{m})$ were processed for immunohistochemistry and stained with antibodies against CK8 to mark OSE or TEC and antibodies against BrdU or PCNA to mark proliferating cells. Asterisks mark proliferating TEC. (C) The percentage of CK8-positive TEC with BrdU incorporation was scored as a percentage of the total number of CK8-positive TEC. Significant differences $(P<0.05)$ are between groups labeled 'a' and 'b.' (D) The percentage of CK8-positive, PCNA-positive TEC was scored as a percentage of the total number of CK8-positive TEC. No significant difference was detected between groups. 
$12 \mathrm{~h}$. Total ovulatory proliferation was measured by ovulating animals $(n=6)$ with PMSG and hCG, with BrdU labeling from $0900 \mathrm{~h}$ on $\mathrm{d} 25$ to $2100 \mathrm{~h}$ on d27.5. At $2100 \mathrm{~h}$ on $\mathrm{d} 27.5$, ovaries and oviducts, including fat pad, bursa, and part of the uterine tube, were collected. For analysis of tissues at $16 \mathrm{~h}$ post-hCG, animals were injected with PBS $(n=4)$ or PMSG $(n=5)$ at $1700 \mathrm{~h}$ on $\mathrm{d} 25$, followed by injection of PBS or hCG at $1700 \mathrm{~h}$ on $\mathrm{d} 27$, and collection of tissues at $0900 \mathrm{~h}$ on $\mathrm{d} 28$. Tissues were fixed in $4 \%$ paraformaldehyde (PFA) for $24 \mathrm{~h}$, dehydrated with ethanol, paraffin embedded, and serial sectioned at $5 \mu \mathrm{m}$.

\section{Organ culture}

Oviducts from d16 prepubertal mice were dissected from the ovary and uterus and gently uncoiled with forceps in dissecting medium composed of Leibovitz (L15) medium with $2 \mathrm{mM}$ L-glutamine, $100 \mathrm{U}$ penicillin, and $100 \mu \mathrm{g}$ streptomycin (Invitrogen). Each oviduct was cut in four pieces, termed organoids. Fallopian tube fimbriae from adult baboons were collected into dissecting medium and the distal ends of the baboon fimbriae were isolated using a scalpel (baboon organoids). Each organoid was placed into a $0.5 \%$ alginate (w/v in PBS) droplet formed on a mesh fiber as described previously (Jackson et al. 2009). The alginate-encapsulated organoid was placed into $50 \mathrm{mM}$ calcium chloride for 2 min to cross-link the alginate into a gel. The encapsulated organoid was then placed into growth media for 7 days. Growth media was composed of alpha-MEM (Invitrogen), $100 \mathrm{U}$ penicillin, and $100 \mu \mathrm{g}$ streptomycin, and $3 \mathrm{mg} / \mathrm{ml}$ BSA (MP Biomedicals, Solon, OH, USA), $10 \%$ v/v FBS (Invitrogen), 10 or $100 \mathrm{mIU} / \mathrm{ml} \mathrm{FSH} \mathrm{(Sigma),} 10$ or $100 \mathrm{mIU} / \mathrm{ml} \mathrm{LH}$ (Sigma), or $10 \mathrm{nM}$ estradiol (Sigma). BrdU was added to the media at a final concentration of $10 \mu \mathrm{M} 24 \mathrm{~h}$ prior to fixation.

\section{Cell culture}

Fallopian tube fimbriae from adult baboons were rinsed briefly in $70 \%$ ethanol and placed into Leibovitz (L15) medium with $1000 \mathrm{U}$ collagenase (Sigma) and $2 \times$ trypsin-EDTA (Invitrogen) for $1 \mathrm{~h}$ at $37^{\circ} \mathrm{C}$. Tissue was vortexed briefly and the media was collected into a new microcentrifuge tube and centrifuged at $800 \mathrm{~g}$ for $3 \mathrm{~min}$ to pellet cells. Cells were maintained in MEM with $10 \%$ FBS, $2 \mathrm{mM}$ L-glutamine, $100 \mu \mathrm{M}$ nonessential amino acids, $1 \mathrm{mM}$ sodium pyruvate, $100 \mathrm{U} / \mathrm{ml}$ penicillin, and $100 \mu \mathrm{g} / \mathrm{ml}$ streptomycin (Invitrogen).

To immortalize the baboon TEC, cells were transfected with $\mathrm{pW} 2 \mathrm{~T}^{+} \mathrm{t}^{+}$to express the SV40 large and small $\mathrm{T}$ antigens (Dr Kathy Rundell, Northwestern University, Chicago, IL, USA) and Lipofectamine 2000 according to the manufacturer's instructions (Invitrogen). Following transfection and subsequent passaging, untransfected cells died, leaving immortalized cells expressing SV40. Cells were cultured for several months and were verified for expression of SV40, secretory, and ciliated markers at passage number 16. The immortalized baboon TEC cell line was named TEC40, for TEC immortalized with SV40.

For proliferation assays, TEC40 cells were seeded into 96 -well plates at $5 \times 10^{4}$ cells $/ \mathrm{ml}$. The next day, complete media containing $10 \%$ FBS and 10 or $100 \mathrm{mIU} / \mathrm{ml} \mathrm{FSH}$ or LH was added to plates and the cells were allowed to grow for 4 days. Proliferation was measured with CellTiter 96 Aqueous One Solution (Promega) according to the manufacturer's directions. Spectrophotometric analysis at $490 \mathrm{~nm}$ was completed using a Biotek EL312e microplate reader (Fisher Biotek, Pittsburgh, PA, USA).

To prepare macrophage-conditioned medium (MCM), RAW264.7 cells were maintained in DMEM with $10 \%$ FBS, $100 \mathrm{U}$ penicillin, and $100 \mu \mathrm{g}$ streptomycin. Conditioned medium was prepared as previously described (An et al. 2009). Cells were plated at $5 \times 10^{5}$ cells $/ \mathrm{ml}$ in a 6 -well plate $24 \mathrm{~h}$ prior to treatment with Escherichia coli lipopolysaccharide serotype O55:B5 (Fisher Scientific, Pittsburgh, PA, USA) in serum-free media. Cells were treated with serum-free media or serum-free media containing $5 \mu \mathrm{g} / \mathrm{ml} \mathrm{lipo-}$ polysaccharide for $24 \mathrm{~h}$ before conditioned media was collected.

For analysis of phospho- $\gamma \mathrm{H} 2 \mathrm{~A} . \mathrm{X}$ foci, TEC40 cells were serum starved for $18 \mathrm{~h}$ prior to treatment with hormones, hydrogen peroxide, or MCM. FSH (10 or $100 \mathrm{mIU} / \mathrm{ml})$, LH $(10$ or $100 \mathrm{mIU} / \mathrm{ml})$, estradiol $(10 \mathrm{nM})$, hydrogen peroxide (Sigma-Aldrich; $1 \mathrm{mM}$ ), or MCM was added to fresh serum-free medium. TEC40 were treated for $20 \mathrm{~min}$, followed by fixation, and immunofluorescent staining as described below.

\section{Luciferase assays}

TEC40 cells were plated in triplicate in phenol red-free DMEM with $10 \%$ charcoal-stripped FBS (Gibco), $100 \mathrm{U} / \mathrm{ml}$ penicillin, and $100 \mu \mathrm{g} / \mathrm{ml}$ streptomycin into 12-well plates $24 \mathrm{~h}$ prior to transfection. Cells were co-transfected with $0.25 \mu \mathrm{g}$ pCMV Sport- $\beta$ gal plasmid and $2.5 \mu \mathrm{g}$ of equal amounts of the ERE-luc reporter plasmid and ER $\alpha$ or pGL3-Basic plasmids using the calcium phosphate precipitation method (Sambrook et al. 1989). The ERE-luc reporter plasmid and $\mathrm{ER} \alpha$ expression plasmids were obtained from 
Dr Benita Katzenellenbogen, University of Illinois, Champaign, IL, USA. After cells were incubated with plasmids for $4 \mathrm{~h}$, cells were washed, glycerol shocked, and incubated in media with or without $50 \mathrm{nM}$ estradiol for $20 \mathrm{~h}$. Cells were harvested in reporter lysis buffer and luciferase activity measured relative to $\beta$-galactosidase activity as described previously (Jaffe et al. 2003).

\section{RNA isolation and RT-PCR}

Total RNA was extracted from $1 \mathrm{mg}$ of adult mouse ovary, d16 mouse oviduct, baboon fimbriae, or $1 \times 10^{6}$ TEC40 cells using a Qiagen Qiashredder column and Qiagen RNeasy kit according to manufacturer's directions (Qiagen, Inc.). cDNA was prepared by reverse transcribing $1 \mu \mathrm{g}$ total RNA using MMLV-RT (Fermentas, Inc., Glen Burnie, MD, USA). cDNA was used for PCR amplification using the following primers: mouse FSHR forward (CCTTGCTCCTGGTCTCCTTG), reverse (CTCGGTCACCTTGCTATCTTG); mouse LHR forward (CGCCCGACTATCTCTCACCTA), reverse (GACAGATTGAGGAGGTT GT CAAA); mouse ER $\alpha$ forward (CAGATAGGGAGCTGGTTCATATG), reverse (GCCAGACGAGACCAATCAT); and mouse GAPDH forward (AGGTCGGTGTGAACGG ATTTG); reverse (TGTA GACCATGTAGTTGAGGTCA). For PCR amplification of baboon cDNA, the following human primers were used: human FSHR forward (GTCATCATCGGATCTGT CACTG), reverse (CA TTCCTCGGGAGGTCAGAAG); human LHR forward (GGAGGCCACGTTGACTTAC C), reverse (CAGTTCACTCTCAGCAAGCAT); human ER $\alpha$ forward (TCCTACCAGACCCTTCAGTG), reverse (GGTCAAATCCACAAAGCC TG); and human GAPDH forward (ATGGGGAAGGTGAAGGTCG), reverse (GGGGTCATTGATGGCAACAATA). Cycling conditions for reactions were $94{ }^{\circ} \mathrm{C} 2 \mathrm{~min} ; 34$ cycles of $94{ }^{\circ} \mathrm{C}$ for $30 \mathrm{~s}$, $55^{\circ} \mathrm{C}$ for $30 \mathrm{~s}, 68{ }^{\circ} \mathrm{C}$ for $30 \mathrm{~s} ; 68^{\circ} \mathrm{C}$ for $5 \mathrm{~min}$. Reactions were run on a $1 \%(\mathrm{w} / \mathrm{v})$ agarose gel and visualized using an Alpha Innotech gel documentation system (Santa Clara, CA, USA).

\section{Immunohistochemistry}

Organoids were removed from culture media, recrosslinked in $50 \mathrm{mM}$ calcium chloride for $2 \mathrm{~min}$, and fixed in $2 \%$ PFA with $50 \mathrm{mM}$ sodium cacodylate and $10 \mathrm{mM}$ calcium chloride for 16-24 h. All reagents were obtained from Vector Laboratories, Inc. (Burlingame, CA, USA) unless otherwise indicated. Xylene and ethanol were obtained from Surgipath Medical Ind., Inc. (Richmond, IL, USA). Antigen retrieval was performed using $10 \mathrm{mM}$ sodium citrate, $\mathrm{pH}$ 6.0. Slides were washed in Tris-buffered saline (TBS) with Tween $20(20 \mathrm{mM}$ Tris, $500 \mathrm{mM} \mathrm{NaCl}$, and $0.1 \%$ Tween 20 , $\mathrm{pH}$ 7.4). When staining for BrdU, tissues were treated with $4 \mathrm{M}$ hydrochloric acid for $10 \mathrm{~min}$, followed by $0.1 \mathrm{M}$ sodium tetraborate for $10 \mathrm{~min}$. Tissues were blocked for $15 \mathrm{~min}$ in 3\% hydrogen peroxide (Fisher Scientific) followed by avidin and biotin blocking according to manufacturer's instructions. Slides were incubated in TBS-3\%BSA-10\% serum of the secondary antibody host for $1 \mathrm{~h}$ at room temperature. After blocking, slides were incubated overnight at $4{ }^{\circ} \mathrm{C}$ in primary antibody in 3\% BSA-TBS-10\% serum. Control slides received serum block instead of the primary antibody. The primary antibodies against BrdU (rat, 1:200 dilution; Abcam, Cambridge, MA, USA), cytokeratin 8 (CK8) (CK8 TROMA-1 antibody, rat, 1:200; Developmental Studies Hybridoma Bank, Iowa City, IA, USA), E-cadherin (rabbit, 1:50; Cell Signaling Technology, Denver, MA, USA), F4/80 (rat, 1:100; Abcam), acetylated tubulin (mouse, 1:500; Sigma-Aldrich), oviductal glycoprotein 1 (OVGP1, rabbit, 1:250; Abcam), Pax8 (rabbit, 1:250 Proteintech Group, Chicago, IL, USA), phospho- $\gamma \mathrm{H} 2 \mathrm{~A} . \mathrm{X}$ (rabbit, 1:100; Cell Signaling Technology), or SV40 T Ag (rabbit 1:50; Santa Cruz Biotechnology, Santa Cruz, CA, USA) were incubated on tissue sections overnight at $4{ }^{\circ} \mathrm{C}$. Slides were rinsed three times for $5 \mathrm{~min}$ in TBS-Tween and then incubated at room temperature for 30 min in biotinylated secondary antibody in $3 \%$ BSA-TBS. After washing slides in TBS-Tween, avidin/biotin complex (ABC) reagent was added and incubated for $30 \mathrm{~min}$ at room temperature. Slides were washed in TBS and antigen-antibody-HRP complex was visualized using diaminobenzidine reagent for 5 min. Slides were counterstained with hematoxylin.

\section{Immunofluorescence}

TEC40 cells were plated in an 8-well chamber slide at a density of $5 \times 10^{4}$ cells per well. Cells were fixed in 4\% PFA for $5 \mathrm{~min}$, washed with PBS, and permeabilized with $0.2 \%$ Triton-X100 in PBS for 10 min. Cells were then washed twice with PBS and blocked with $10 \%$ goat serum in PBS for $10 \mathrm{~min}$. Cells were incubated in primary antibody diluted in $10 \%$ serum in PBS for $1 \mathrm{~h}$ at room temperature. Cells were washed and incubated with anti-rat AlexaFluor-594-conjugated secondary antibodies (Invitrogen) for $30 \mathrm{~min}$ to detect CK8 staining. For double immunofluorescent staining of CK8 and phospho- $\gamma \mathrm{H} 2 \mathrm{~A} . \mathrm{X}$, cells were incubated with anti-rat AlexaFluor 594 and anti-rabbit AlexaFluor 488 for $30 \mathrm{~min}$. For all other double 
immunofluorescent staining, cells were incubated with both AlexaFluor594 and a biotinylated anti-rabbit secondary antibody for $30 \mathrm{~min}$. Cells were washed with PBS and incubated with $\mathrm{ABC}$ reagent for $30 \mathrm{~min}$. After washing with PBS, cells were fluorescently labeled with AlexaFluor488 using a streptavidin-HRP tyramide signal amplification kit (TSA kit \#22, Invitrogen) for $10 \mathrm{~min}$ at room temperature. Cells were washed in distilled water and slides were mounted with Vectashield Mounting Medium with DAPI (Vector Laboratories). The proliferating cell nuclear antigen antibody (PCNA; rat) was used according to the manufacturer's protocol (Zymed, San Francisco, CA, USA).

\section{Western blotting}

TEC40 cells were serum-starved overnight prior to treatment with FSH $(10$ or $100 \mathrm{mIU} / \mathrm{ml})$ or $\mathrm{LH}(10$ or $100 \mathrm{mIU} / \mathrm{ml}$ ) in serum-free media for $24 \mathrm{~h}$. Cells were lysed in modified RIPA buffer $(25 \mathrm{mM}$ Tris- $\mathrm{HCl}$, $\mathrm{pH} 7.6,150 \mathrm{mM} \mathrm{NaCl}, 1 \%$ (v/v) Triton-X, 1\% (v/v) sodium deoxycholate, $0.1 \%$ SDS, $1 \times$ Complete Mini Protease Inhibitor Cocktail tablets (Roche), and $1 \times$ Phosphatase Inhibitor Cocktail III (Sigma)). Protein concentration was determined using the bicinchoninic acid assay (Pierce, Rockford, IL, USA). Cell lysate $(30 \mu \mathrm{g})$ was run on a $10 \%$ SDS-PAGE gel under reducing conditions and transferred to polyvinylidene fluoride membrane. Membranes were blocked for $1 \mathrm{~h}$ at RT in 5\% BSA (for pERK1/2) or 5\% nonfat dry milk (for actin) in TBS-T. Primary antibodies against phospho-p44/42 MAPK (Erk1/2) (Thr 202/Tyr204) (rabbit, 1:1000 dilution; Cell Signaling Technology) or actin (rabbit, 1:1000 dilution; Sigma) were incubated on blots overnight at $4{ }^{\circ} \mathrm{C}$. After washing, membranes were incubated with goat anti-rabbit HRP secondary antibody (Cell Signaling) at 1:1000 in blocking buffer for $1 \mathrm{~h}$. Membranes were washed and incubated with SuperSignal West Femto substrate (Thermo Scientific, Rockford, IL, USA) before imaging on an Alpha Innotech gel documentation system.

\section{Imaging and counts}

Immunohistochemistry or immunofluorescent images were acquired on a Nikon E600 microscope using a DXM1200 digital camera and NIS Elements software (Nikon Instruments, Melville, NY, USA). Immunofluorescent images were also acquired on a Zeiss LSM510 laser scanning confocal microscope (Carl Zeiss MicroImaging, LLC, Thornwood, NY, USA). Using ImageJ software (National Institutes of Health,
Bethesda, MD, USA), the number of CK8-positive tubal cells that were also positive for BrdU, PCNA, or phospho- $\gamma$ H2A.X were counted and expressed as a percentage of total number of CK8-positive tubal cells. At least three random fields from at least two independent experiments were counted.

\section{Statistical analysis}

All values are expressed as the mean \pm s.E.M. Tukey's multiple comparison tests were used to assess differences between experimental groups and control groups. For comparison between two groups, a Student's $t$-test was used. $P<0.05$ was considered statistically significant.

\section{Results}

\section{Ovulation does not drive proliferation of TEC in vivo}

In order to investigate whether ovulation increases proliferation of TEC, incorporation of BrdU was quantified in control $\mathrm{CD} 1$ mice or mice that were hormonally induced to ovulate (Fig. 1A). Day 25 immature mice were used to ensure that no previous ovulations had occurred, leaving the ovaries and oviducts undamaged by previous ovulation-related inflammation, wound repair, or the influence of hormones. Mice were injected with either PBS as a control or a combination of 5 IU PMSG and hCG to induce ovulation $(n=6)$ (Burdette et al. 2006). Ovulation was verified to have occurred by the presence of corpora lutea within the ovary. Proliferation in response to both PMSG and hCG (BrdU treatment on $\mathrm{d} 25,60 \mathrm{~h}$ labeling period) and post-ovulatory proliferation in response to hCG injection (BrdU treatment on $\mathrm{d} 27,12 \mathrm{~h}$ labeling period) were determined and compared to proliferation in PBS-treated animals. To quantify the percentage of proliferating TEC, serial sections of oviduct were stained with antibodies against CK8 to mark epithelial cells, or BrdU to mark proliferating cells (Fig. 1B). Tubal cells positive for both $\mathrm{CK} 8$ and $\mathrm{BrdU}$ were scored as a percentage of total CK8-positive tubal cells (Fig. 1B and C). For TEC, animals in the abridged basal group showed 3.5\% proliferating cells compared with $6.3 \%$ proliferating cells in the post-ovulatory group, over the course of a $12 \mathrm{~h}$ labeling period. The total basal animals exhibited $18.5 \%$ proliferating epithelial cells compared with $17.7 \%$ in the total ovulatory animals, both of which underwent labeling for $60 \mathrm{~h}$. Significant differences were not detected when comparing ovulated animals 
to unstimulated animals and controlling for labeling time in vivo.

To verify TEC proliferation using an endogenous marker of proliferation, serial sections were stained for CK8 or PCNA and counted as described above (Fig. 1B). Basal animals included both total basal and abridged basal animals, as the only difference between these groups was the time of BrdU incorporation, which was not necessary for measuring PCNA $(n=9)$. Ovulated animals included both total ovulatory and post-ovulatory animals $(n=12)$. In accordance with the measurement of BrdU labeling as an indicator of cell proliferation, basal animals showed $7.0 \%$ PCNApositive cells, compared with $9.0 \%$ for ovulated, which was not significantly different (Fig. 1D). Therefore, ovulation does not increase TEC proliferation in vivo.

\section{Three-dimensional oviduct culture system retains markers of secretory and ciliated cells}

To determine the effects of individual components of ovulation, such as the gonadotropins and inflammation, on TEC proliferation and DNA damage, a threedimensional organ culture system was developed to study normal primary TEC in their microenvironment. Alginate, a widely used biomaterial in tissue engineering, was used as described previously (Jackson et al. 2009) to maintain the physiological architecture of the oviduct, with the TEC lining the lumen of the tube. Sexually immature d16 CD1 mice were used in order to study oviductal epithelium that had not been affected by ovulations. Each oviduct was separated into four pieces with a scalpel and placed into an alginate droplet (Fig. 2) and cultured for 7 days in basal media (BSA or FBS) or serum-free media supplemented with FSH, LH, or estradiol at cycling or menopausal concentrations (King et al. 2011). Oviducts were analyzed by immunohistochemistry for normal endogenous markers of TEC and compared to uncultured mouse oviducts (Fig. 3A and Supplementary Figure 1, see section on supplementary data given at the end of this article). The oviduct culture system retained cytoplasmic markers of normal oviductal epithelium, CK8 and E-cadherin. As assayed by PCNA staining, cultured and uncultured oviducts exhibited similar TEC proliferation rates (Supplementary Figure 1, see section on supplementary data given at the end of this article). Cultured oviducts continued to express oviductin (OVGP1), a secreted glycoprotein characteristic of the oviduct (Umezu et al. 2003). A subpopulation of TEC from cultured and uncultured oviducts stained positively for nuclear expression of Pax8, a marker of secretory cells in the oviduct, while a separate subpopulation of TEC stained positively for acetylated tubulin, a marker of ciliated cells.

In primates, the TEC of the distal fimbriae of the fallopian tube are comparable to the TEC of the mouse
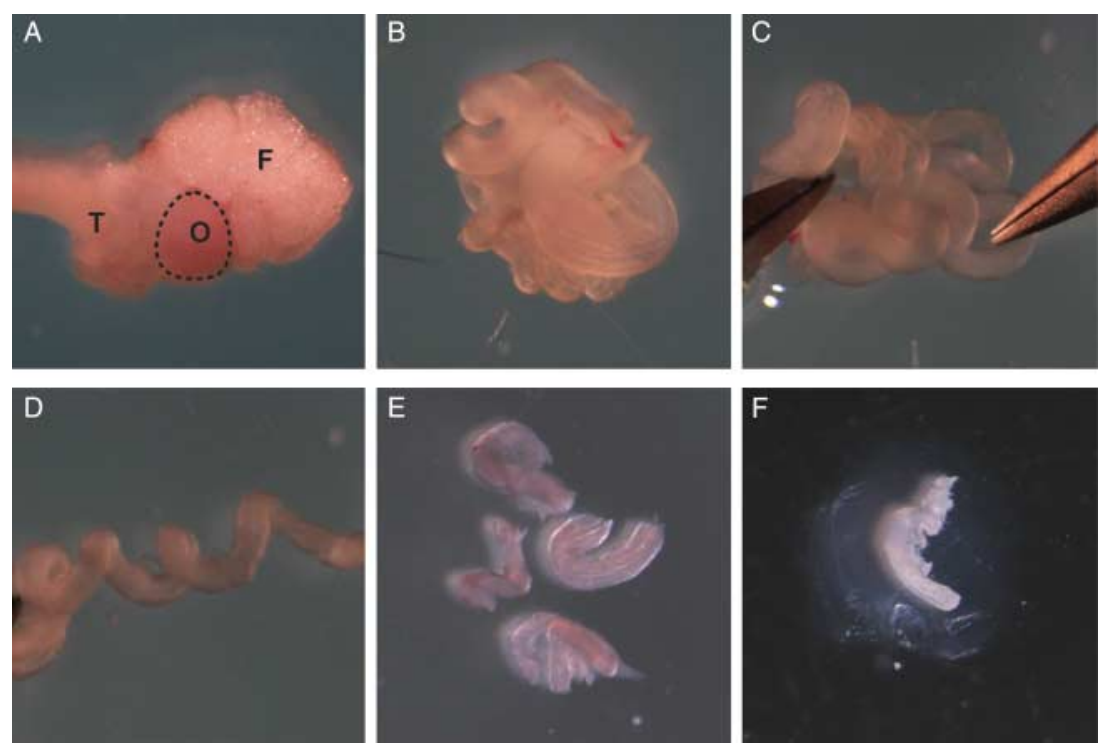

Figure 2 Establishment of a three-dimensional mouse oviduct culture system. (A) Ovary with fat pad and bursal membrane, oviduct, and part of the uterine horn were dissected from sexually immature CD1 mice. $F$, fat pad; $O$, ovary; $T$, oviduct. (B) Ovary and uterine horn were dissected away, leaving oviduct. (C and D) Using forceps, oviduct was gently uncoiled. (E) Each oviduct was cut into four pieces with a scalpel. (F) Each segment of oviduct was embedded in alginate hydrogel and cultured for 7 days. 

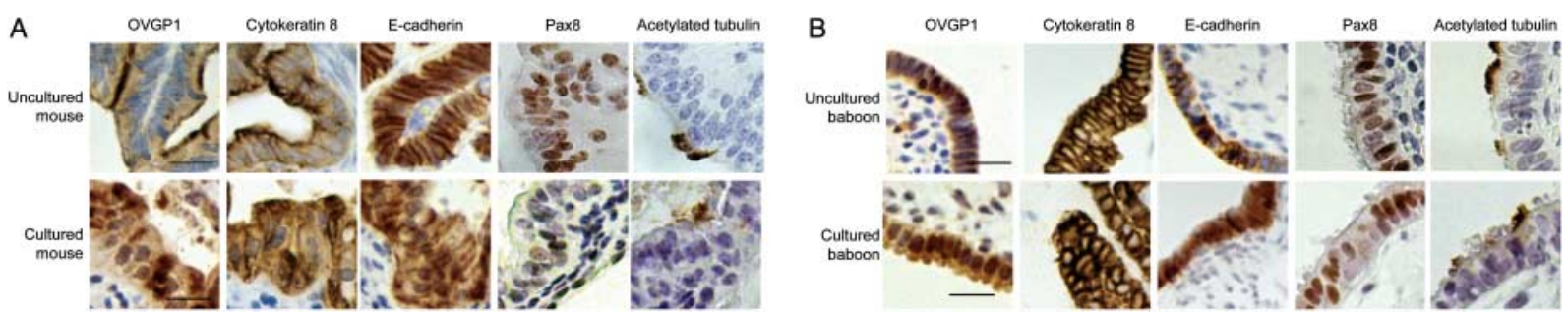

Figure 3 Verification of a three-dimensional mouse oviduct and baboon fimbria organ culture system. (A) Tissues from uncultured mouse oviducts (top panel) or oviducts cultured for 7 days (bottom panel) were processed for immunohistochemistry and stained with antibodies against OVGP1 (oviductin and tubal epithelium), CK8 (simple epithelium), and E-cadherin (tubal epithelium).

Serial sections were stained for Pax8 (secretory tubal epithelium) and acetylated tubulin (ciliated tubal epithelium). (B) Tissues from uncultured baboon fimbriae (top panel) or fimbriae cultured for 7 days (bottom panel) were processed for immunohistochemistry and stained with antibodies against OVGP1, CK8, and E-cadherin. Serial sections were stained for Pax8 and acetylated tubulin. Calibration bars, $20 \mu \mathrm{m}$.

oviduct (Critoph \& Dennis 1977, Komatsu \& Fujita 1978). However, TECs are found on the outer surface of the fimbriae and are in contact with the ovary and face the peritoneal cavity, rather than facing the lumen of the oviduct as in mice. To account for these anatomical differences between mice and primates, a threedimensional culture system for distal baboon fimbriae was developed using the alginate hydrogel method described above (Jackson et al. 2009). Adult female baboons $(n=3)$ were killed and individual fimbria was placed into alginate hydrogel droplets and cultured for 7 days. Cultured and uncultured fimbriae were evaluated by immunohistochemistry for markers of secretory and ciliated cells (Fig. 3B and Supplementary Figure 1, see section on supplementary data given at the end of this article). Fimbria cultures retained markers of TEC (CK8, E-cadherin), oviductin expression, and similar levels of cell proliferation (PCNA). A subpopulation of baboon fimbriae TEC was positive for expression of acetylated tubulin, while other TECs were positive for expression of Pax8, a marker of secretory cells. Therefore, the three-dimensional organ culture system for mouse oviduct and baboon fallopian tube fimbriae retains markers of the cell types normally present in these tissues.

\section{Immortalization of baboon fimbriae TEC allows co-culture of secretory and ciliated cells}

An immortalized baboon fimbriae TEC cell line (TEC40; TEC immortalized with SV40) was generated to observe the effects of individual aspects of ovulation on cultured TEC. Development of a two-dimensional immortalized TEC cell line allows for comparison of immortalized TEC to immortalized OSE cells (IOSE cells) and to previous studies using traditional twodimensional culture on plastic of normal and cancer cell lines. TEC40 cells retained an epithelial morphology and were analyzed for retention of ciliated and secretory cell markers by immunofluorescence at passage number 16, after several weeks in culture (Fig. 4A-F). As demonstrated in the baboon fimbriae organ culture system, TEC40 retained the epithelial cell markers CK8, E-cadherin, and expression of the secreted glycoprotein OVGP1. A subset of cells was positive for Pax8, while another subset was positive for acetylated tubulin. TEC40 exhibited immunofluorescence staining for $\mathrm{SV} 40 \mathrm{~T} / \mathrm{t}$, indicating that the cultured cells were immortalized by expression of the viral oncogenes that disrupt p53 and retinoblastoma.

To determine whether TEC40 were responsive to FSH and LH signaling, cells were treated with cycling or menopausal levels of hormones and analyzed for expression of phospho-MAPK (pERK1/2), which is downstream of both FSH and LH signaling in OSE and granulosa cells (Choi et al. 2002, 2009). Cells treated with FSH or LH showed a dose-dependent accumulation of phospho-MAPK (pERK1/2), indicating that FSH and LH signaling is present in TEC40 cells (Fig. 4G). Additionally, transcripts for FSHR and LHR were detected in TEC40 cells (Supplementary Figure 2, see section on supplementary data given at the end of this article).

To determine whether TEC40 cells were responsive to estradiol, cells were co-transfected with pCMV Sport- $\beta$ gal and ERE-luciferase reporter plasmids, with or without co-expression of a plasmid expressing ER $\alpha$. TEC40 exhibited no significant change in activation of the ERE-luciferase reporter relative to the $\beta$-galactosidase reporter when cells were treated with $50 \mathrm{nM}$ estradiol. This corresponds to a lack of expression of ER $\alpha$ in TEC40 cells as assayed by RT-PCR (Supplementary Figure 2, see section on supplementary data given at the end of this article). When ER $\alpha$ was overexpressed, TEC40 cells exhibited approximately fourfold induction of the ERE-luciferase reporter (Fig. $4 \mathrm{H})$. 

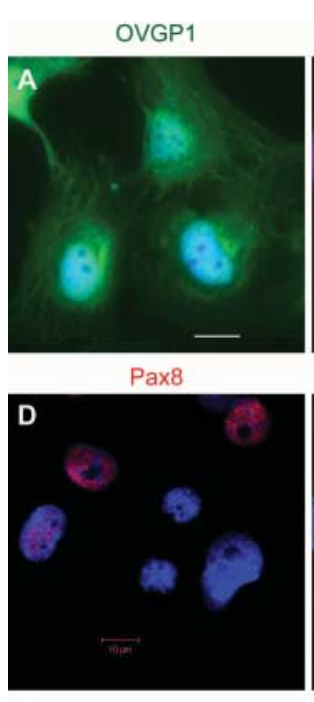

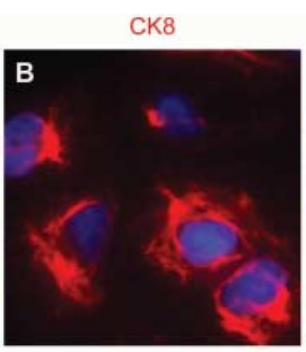

Acetylated tubulin

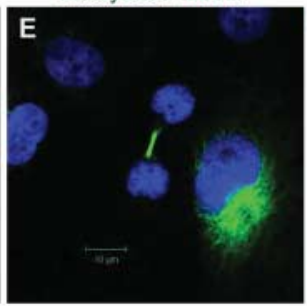

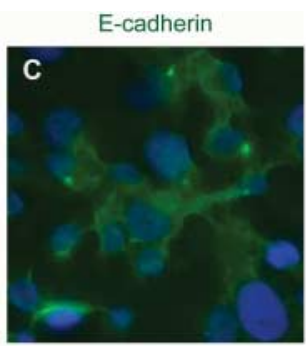

SV40

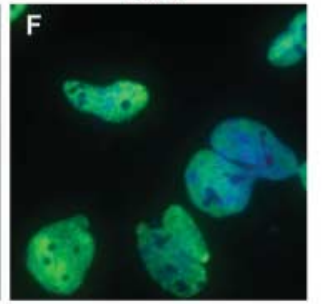

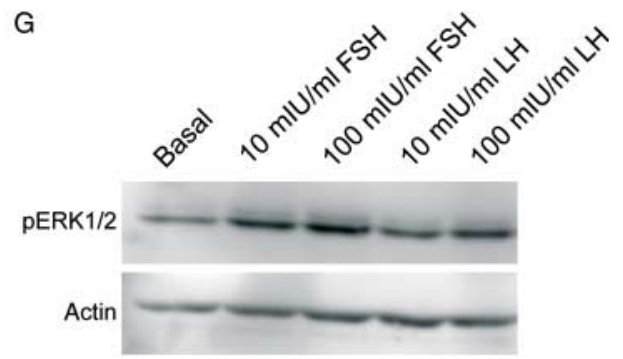

$\mathrm{H}$

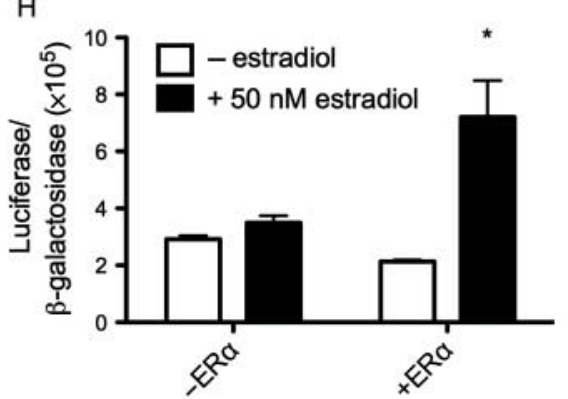

Figure 4 TEC40 tubal epithelium cell line retains markers of secretory and ciliated cells. Immortalized TEC40 were plated into 8-well chamber slides, fixed, and analyzed by immunofluorescence for epithelial cell markers OVGP1, CK8, and E-cadherin (A-C); secretory cell marker Pax8 (D); and ciliated cell marker acetylated tubulin (E) as well as for expression of SV40 T/t antigen (F). Calibration bar, $10 \mu \mathrm{m}$. (G) TEC40 cells treated with FSH or LH for $24 \mathrm{~h}$ were analyzed for expression of $\mathrm{pERK} 1 / 2$ or actin as a loading control by western blotting. $(\mathrm{H})$ TEC40 cells were analyzed for activation of ERE-luciferase construct relative to activation of $\beta$-galactosidase reporter construct in response to estradiol or cotransfection of ER $\alpha$. Data represent average \pm S.E.M. ${ }^{*} P<0.05$.

\section{TECs do not proliferate in response to $\mathrm{FSH}, \mathrm{LH}$, or estradiol}

The mouse oviduct and baboon fimbriae organ culture systems were used to evaluate the effects of FSH, LH, and estradiol on TEC proliferation in vitro. For mouse oviduct cultures, no significant increase in proliferation was observed in response to FSH, LH, or estradiol compared with BSA or FBS controls. Cycling levels of FSH or estradiol suppressed TEC cell proliferation (Fig. 5A). For baboon fimbriae cultures, no significant difference in proliferation was observed for tissues cultured with FSH, LH, or estradiol (Fig. 5B). To verify the presence of FSHR, LHR, and ER $\alpha$ in these tissues, RNA was extracted from adult mouse ovary as a positive control, d16 mouse oviduct, and adult baboon fimbriae and subjected to RT-PCR. Transcripts for FSHR, LHR, and ER $\alpha$ were detected in the mouse ovary and oviduct and the baboon fimbriae, though FSHR shows weak expression in mouse oviduct (Supplementary Figure 2, see section on supplementary data given at the end of this article).

Since TEC40 cells were responsive to FSH and LH, but not estradiol (Fig. 4G and H), TEC40 cells were analyzed for proliferation in response to cycling and menopausal levels of FSH and LH. After 4 days in culture, cells cultured in cycling $(10 \mathrm{mIU} / \mathrm{ml})$ levels of
FSH showed a slight but statistically significant increase in proliferation (Fig. 5C). No difference in proliferation was observed at higher concentrations of FSH or LH.

\section{Ovulation induces inflammation and oxidative stress in vivo}

As ovulation did not stimulate TEC proliferation in vivo through a tear-and-repair process (Fig. 1), and menopausal levels of gonadotropins did not induce proliferation in mouse oviduct organ culture, baboon fimbriae organ culture, or immortalized TEC40 cells (Fig. 5), ovulation-induced inflammation in TEC was evaluated. Tissues from control mice or ovulated mice were analyzed for nuclear phospho$\gamma \mathrm{H} 2 \mathrm{~A} . \mathrm{X}$ foci 12 or $16 \mathrm{~h}$ after hCG injection (Fig. 6A). Phospho- $\gamma \mathrm{H} 2 \mathrm{~A}$.X is a histone protein incorporated at sites of double-strand DNA breaks, which are frequently formed due to exposure to oxidative damage (Bartkova et al. 2005). In control animals, $6.5 \%$ of TEC exhibited phospho- $\gamma \mathrm{H} 2 \mathrm{~A} . \mathrm{X}$ foci compared with $20.0 \%$ of TEC from ovulated animals at $12 \mathrm{~h}$ post-hCG and $16.3 \%$ of TEC from ovulated animals at $16 \mathrm{~h}$ post-hCG (Fig. 6B). No difference in proliferation rates were observed in TEC from 

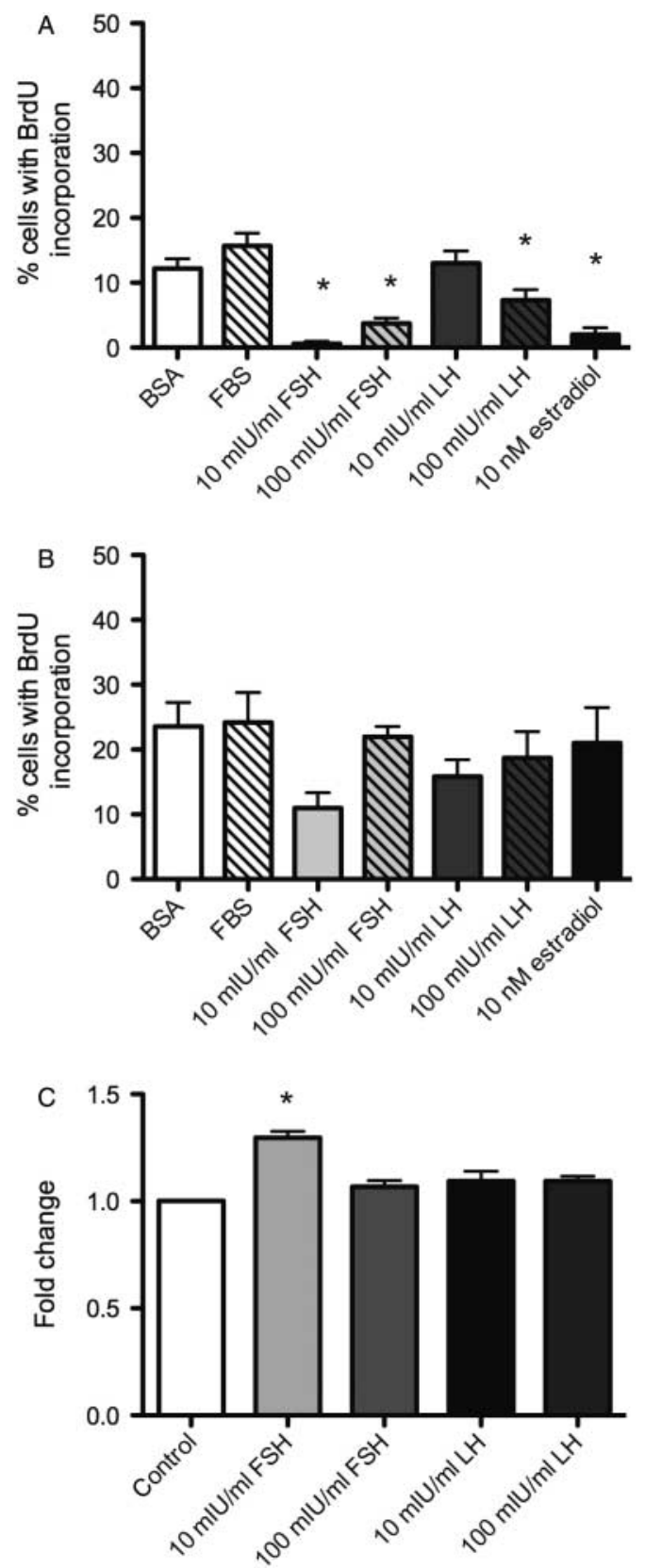

Figure 5 Gonadotropins do not increase proliferation in TEC. (A and B) After 7 days in culture medium containing $10 \%$ FBS, $3 \mathrm{mg} / \mathrm{ml} \mathrm{BSA}$, cycling levels $(10 \mathrm{mlU} / \mathrm{ml})$, or menopausal levels $(100 \mathrm{mIU} / \mathrm{ml})$ of $\mathrm{FSH}$ or $\mathrm{LH}$, or $10 \mathrm{nM}$ estradiol, tissues were processed for immunohistochemistry. Serial sections were stained with antibodies against CK8 and BrdU and the percentage of CK8-positive TEC with BrdU incorporation was scored relative to the total number of CK8-positive TEC. (A) Cell proliferation in mouse oviduct culture. (B) Cell proliferation in baboon fimbriae culture. (C) TEC40 cells were cultured with cycling levels $(10 \mathrm{mIU} / \mathrm{ml})$ or menopausal levels $(100 \mathrm{mIU} / \mathrm{ml})$ of the gonadotropins FSH and LH for 3 days. Proliferation in response to hormones was measured by MTS assay for viability. Data represent average fold change \pm S.E.M. compared with control. ${ }^{\star} P<0.05$. ovulated animals at $12 \mathrm{~h}$ compared with $16 \mathrm{~h}$ post-hCG (data not shown).

It is possible that the DNA damage observed in vivo in response to ovulation may be due to the inflammatory reaction associated with ovulation. Macrophage infiltration into human fallopian tube mucosa has previously been demonstrated in response to ovulation, and macrophages are known to secrete pro-inflammatory mediators (Gaytan et al. 2007). Therefore, oviducts from control or ovulated mice were analyzed for expression of F4/80 antigen, a surface glycoprotein that is expressed by macrophages during maturation and activation in response to inflammation (Austyn \& Gordon 1981, RobinsonSmith et al. 2007). Control animals showed no macrophage infiltration, while macrophages were found at the periphery of oviducts of ovulated animals at $12 \mathrm{~h}$ after hCG injection (Fig. 6C). At $16 \mathrm{~h}$ after hCG injection, macrophages were found at the periphery of oviducts, adjacent to cumulus-oocyte complexes, and associated with the tubal epithelium. Therefore, macrophage infiltration and phospho- $\gamma \mathrm{H} 2 \mathrm{~A}$.X foci are detected in the oviduct after ovulation in vivo.

To determine which aspect of ovulation correlates with increased DNA damage, TEC40 cells were treated with cycling or menopausal levels of FSH or $\mathrm{LH}$ or $10 \mathrm{nM}$ estradiol to examine the impact of hormonal components of ovulation on DNA damage. To analyze the effects of oxidative stress associated with inflammation, $1 \mathrm{mM}$ hydrogen peroxide, macrophage-conditioned media from RAW264.7 cells (MCM), or MCM from RAW264.7 cells stimulated with E. coli lipopolysaccharide (MCM+ LPS) was added to TEC40 cells. Cells were analyzed for the presence of phospho- $\gamma \mathrm{H} 2 \mathrm{~A}$.X foci after treatment with basal media, hormone, hydrogen peroxide, MCM, or MCM+LPS (Fig. 7). In response to hydrogen peroxide or MCM+LPS, a significant increase in DNA damage was observed.

\section{Discussion}

In addition to a family history of breast and ovarian cancer, a primary risk factor for serous ovarian cancer is an increased number of lifetime ovulations (Auersperg et al. 1997). While the OSE is a commonly accepted site of origin for many histotypes of ovarian cancer, emerging evidence suggests that the TEC may be an alternative source for high-grade serous cancer (Crum et al. 2007b). The goal of this study was to examine the impact of ovulation on TEC by evaluating three commonly accepted hypotheses regarding the origin of ovarian cancer - the tear-and-repair 
A

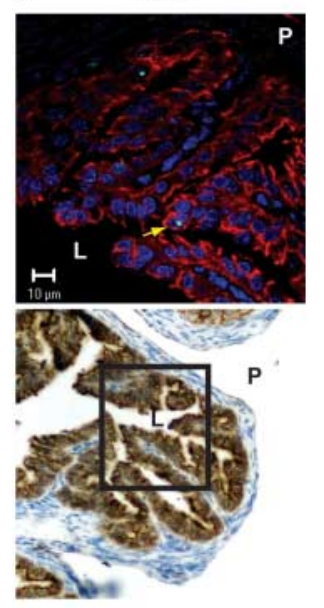

$12 \mathrm{~h}$ post-hCG

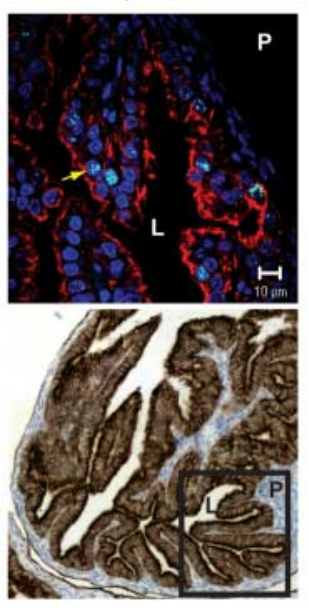

$16 \mathrm{~h}$ post-hCG

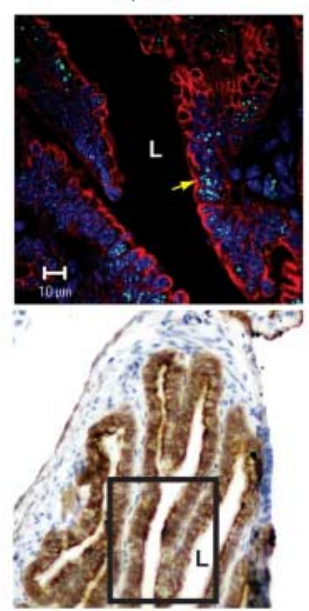

B

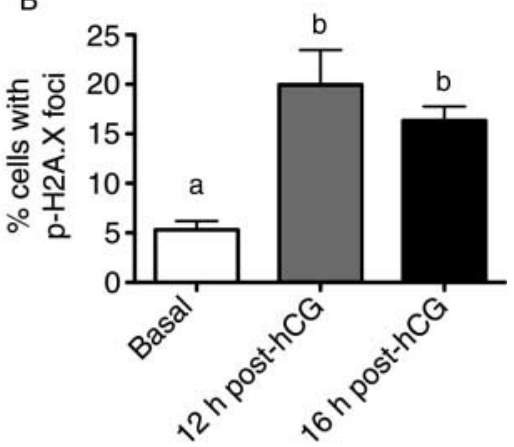

C
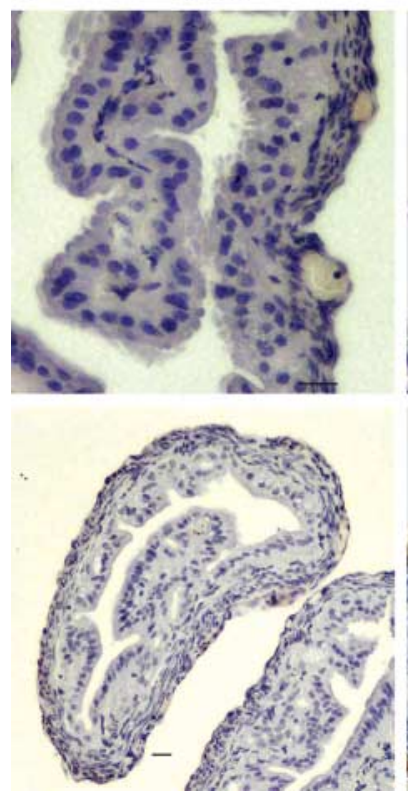

Basal
$12 \mathrm{~h}$ post-hCG

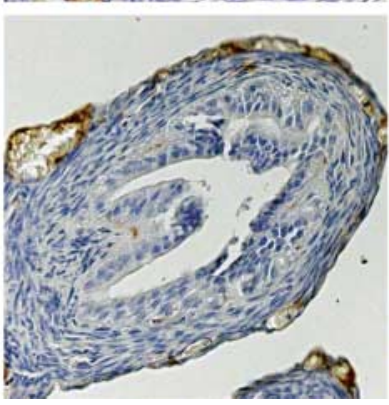

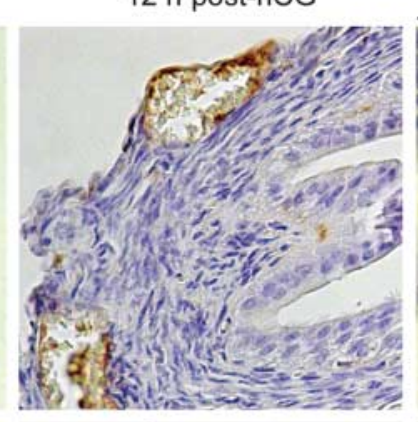

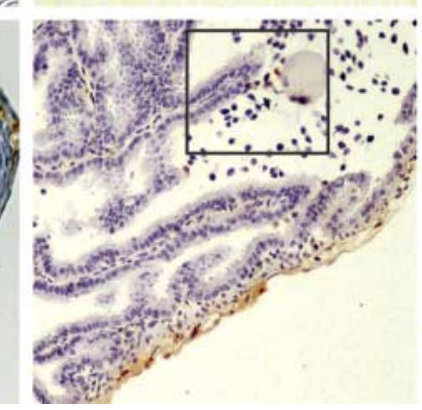

$16 \mathrm{~h}$ post-hCG
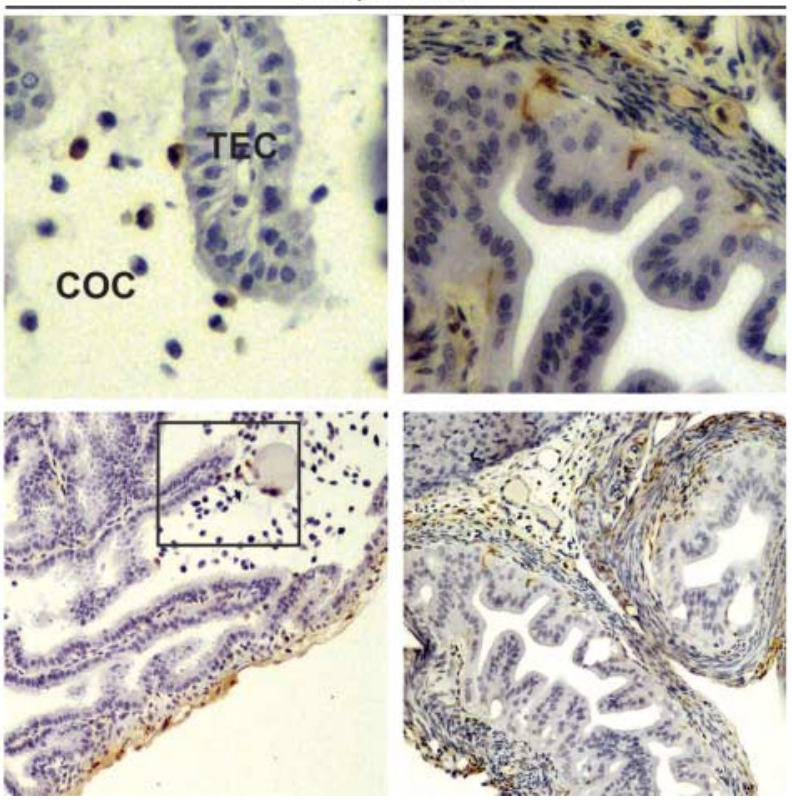

Figure 6 Ovulation induces double-strand DNA breaks in vivo and increases oviduct-associated macrophages. (A) Oviducts from basal or ovulated mice (12 or $16 \mathrm{~h}$ post-hCG) were sectioned and analyzed by immunohistochemistry for CK8 (red), phospho$\gamma$ H2A.X (green), and DAPI (blue). Calibration bars, $10 \mu \mathrm{m}$. Lower panels show CK8 staining (brown), which indicates the location of TEC cells. Upper panels are higher magnification of boxed area in lower panel. L, lumen of oviduct; $P$, periphery of oviduct. Yellow arrows point to damaged nuclei. (B) Positive cells were scored as CK8-positive TEC cells with nuclear phospho- $\gamma \mathrm{H} 2 \mathrm{~A}$.X nuclear foci, relative to the total number of CK8-positive TEC cells. Data represents average fold change \pm S.E.M. compared with control. Significant differences $(P<0.05)$ are between groups labeled a and $\mathrm{b}$. (C) Oviducts from basal or ovulated mice $(12$ or $16 \mathrm{~h}$ post-hCG) were sectioned and analyzed by immunohistochemistry for F4/80 macrophage glycoprotein (brown staining indicates antigen). COC, cumulus oocyte complex. Top panel, total magnification $400 \times$. Bottom panel, total magnification $200 \times$. Calibration bars, $20 \mu \mathrm{m}$.

hypothesis, the gonadotropin hypothesis, and the inflammation hypothesis. Despite well-documented increases in OSE proliferation in the CD1 mouse strain $12 \mathrm{~h}$ post-hCG injection (Burdette et al. 2006), TEC in this study did not proliferate in response to ovulation in vivo, at either 12 or $16 \mathrm{~h}$ post-hCG injection.
However, it is possible that TEC proliferation may occur at a more distant time point following ovulation. Although no increase in TEC proliferation was observed at these early time points following ovulation, heightened DNA damage and macrophage infiltration were detected. 

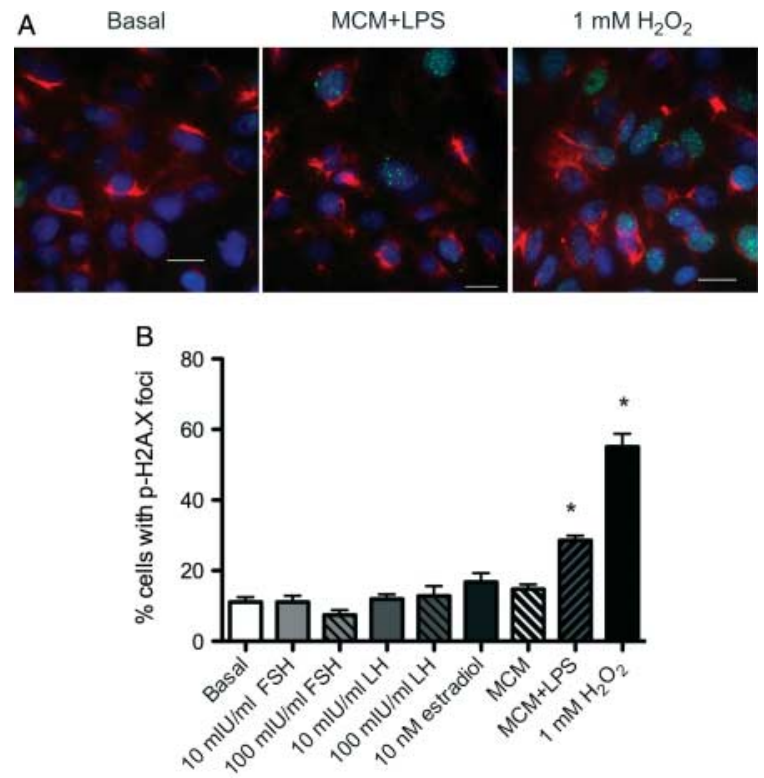

Figure 7 Oxidative stress induces double-strand DNA breaks in TEC40 cells. TEC40 cells were plated into 8-well chamber slides and incubated with serum-free medium, containing cycling concentrations $(10 \mathrm{mIU} / \mathrm{ml})$ or menopausal concentrations $(100 \mathrm{mlU} / \mathrm{ml})$ of $\mathrm{FSH}$ or $\mathrm{LH}, 10 \mathrm{nM}$ estradiol, $1 \mathrm{mM}$ hydrogen peroxide, MCM, or MCM + LPS for 20 min. (A) Cells were analyzed by immunofluorescence for CK8 (red), phospho$\gamma \mathrm{H} 2 \mathrm{~A} . \mathrm{X}$ (green), and DAPI (blue). Calibration bars, $20 \mu \mathrm{m}$. (b) Positive cells were scored as those that exhibited phospho$\gamma \mathrm{H} 2 \mathrm{~A}$.X nuclear foci, relative to the total number of TEC40 cells as analyzed by DAPI staining. Data represent average fold change \pm S.E.M. compared with basal. ${ }^{\star} P<0.05$.

In order to examine the components of ovulation that may contribute to fallopian tube neoplasia, such as the influence of gonadotropins and inflammatory factors on TEC proliferation and DNA damage, novel tools were developed. Using an alginate hydrogel matrix, sections of mouse oviduct or baboon distal fimbriae were cultured in a three-dimensional organ culture system, allowing for precise control of hormones or growth factors in contact with TEC. This system offers certain advantages over traditional cell culture, including retention of the underlying stromal tissue, and culture of non-transformed, non-immortalized cells. However, luminal structures are particularly sensitive to constriction within an alginate matrix, as has been observed for follicular antrum formation (Xu et al. 2006, West-Farrell et al. 2009). Compared with uncultured mouse oviducts, those cultured in alginate for 7 days showed a reduction in the thickness of the epithelial layer lining the interior of the oviduct, which likely reflects compression of the oviductal lumen due to growth within the alginate gel. Despite this compression, the cultured mouse oviducts showed similar rates of proliferation of TEC as observed in uncultured oviducts and retained both secretory and ciliated epithelium, with the highest proportion of ciliated cells found in sections of the oviduct closest to the ovary (infundibulum and ampulla) and decreasing toward the uterus (isthmus). This study also used baboon fallopian tube epithelium, which is structurally similar to human tissue with the TEC on the outer surface of the tissue. As a corollary to the organ culture system, an immortalized baboon fallopian tube cell line was generated that retained both secretory and ciliated TEC, allowing for comparative analysis of the effects of the gonadotropins on cell growth on twodimensional plastic versus three-dimensional organ culture, as well as a renewable source of cells for studies on downstream signaling pathways and neoplastic transformation in TEC. The TEC40 cells were immortalized with SV40, which allows direct comparison of the IOSE cell lines that were generated in a similar manner (Auersperg et al. 1994, Karst et al. 2011). Similar to the IOSE cells and immortalized human TEC, the TEC40 cells do not form colonies in soft agar (data not shown), indicating that they could be used to model early transformative events (Karst et al. 2011).

Using three-dimensional organ culture to evaluate the gonadotropin hypothesis of ovarian cancer demonstrated that although FSH and LH at the tonically high levels observed during menopause induce proliferation of OSE, no increase in proliferation or DNA damage was detected in TEC, despite a common embryonic origin for these cells in the coelomic epithelium (Auersperg et al. 2008, Auersperg 2011). Transcripts for FSHR, LHR, and ER $\alpha$ were detected in the mouse oviduct and baboon fimbriae, indicating that signaling components responsive to $\mathrm{FSH}, \mathrm{LH}$, and estradiol are present in the tissues. Interestingly, in the mouse oviduct cultures, the gonadotropins suppressed proliferation of TEC, which may be due to a lack of growth factors in the media permitting analysis of the isolated effects of each hormone, whereas in vivo the cells are exposed to a variety of cytokines, growth factors, and hormones, resulting in a slightly higher basal rate of proliferation. At cycling levels, FSH caused a significant increase in TEC40 cell proliferation. Although these cells are morphologically normal, expression of SV40 T/t antigen disrupts p53 and retinoblastoma, leading to genetic changes in the cells that may allow for potential alterations in FSHmediated signaling. The TEC40 cells exhibited little or no expression of $\mathrm{ER} \alpha$, which may also be reflective of altered signaling related to immortalization of the cells with SV40 or loss of receptor in long-term culture. 
Oviduct TEC expressed increased levels of phospho$\gamma \mathrm{H} 2 \mathrm{~A} . \mathrm{X}$, a marker of double-strand DNA breaks, after ovulation at 12 and $16 \mathrm{~h}$ after administration of hCG. Using the oviduct and fimbriae organ culture systems to determine whether FSH or LH caused DNA damage revealed no increase in phospho- $\gamma \mathrm{H} 2 \mathrm{~A}$.X foci relative to controls as expected, as FSH and LH have not been shown to generate reactive oxygen radicals. Metabolites of estradiol have been shown to generate reactive oxygen species, increase inflammation, and play a role in progression of hormone-responsive cancers (Straub 2007). Postmenopausal estrogen therapy has been correlated with an increased risk of ovarian cancer, but the effect of estrogens on TEC is unknown (Ness et al. 2002). However, treatment of TEC with estradiol did not increase proliferation or DNA damage in culture after 7 days. Hydrogen peroxide has been frequently used to model oxidative stress generated by ovulation (Murdoch et al. 2001, Symonds et al. 2008). TEC40 cells treated with hydrogen peroxide or MCM + LPS exhibited increased levels of phospho$\gamma \mathrm{H} 2 \mathrm{~A} . \mathrm{X}$ foci, providing a common lesion in cell lines exposed to oxidative stress and in TEC in vivo after ovulation. Induction of H2A.X foci in response to oxidative stress was not likely a result of the altered p53 and Rb status of the TEC40 cells, as OVCA420 cells, which express wild-type p53 and Rb, exhibited similar levels of DNA damage in response to hydrogen peroxide or MCM + LPS (data not shown).

Ovulation caused an increase in activated macrophages associated with the oviduct and suggests one potential mechanism for how cells proximal to the site of ovulation may be susceptible to DNA damage. At $12 \mathrm{~h}$ post-hCG administration, activated macrophages were found primarily at the periphery of oviducts, likely associated with blood vessels, where they may be available for extravasation into the tubal epithelium. At $16 \mathrm{~h}$ post-hCG, examination of oviducts showed the presence of cumulus-oocyte complexes within the oviductal lumen, and activated macrophages were observed adjacent to and in contact with tubal epithelium near sites of ovulated oocytes. Macrophages associate with cumulus-oocyte complexes (Akkoyunlu et al. 2003), which together with the expelled follicular fluid from the site of ovulation may contain reactive oxidants that act on the tubal epithelium. The cumulus-oocyte complexes in the oviduct may release cytokines that promote further invasion of the macrophages into the tubal epithelium from local blood vessels (Zolti et al. 1991). Through release of cytokines and increase in cyclooxygenase (COX) enzymes associated with leukocyte infiltration into the ovary, ovulation increases levels of reactive oxidants, leading to formation of DNA adducts, base modifications, and strand breaks (Croteau \& Bohr 1997, Murdoch 2008, Jabbour et al. 2009). This is the first study to show that ovulation can influence DNA damage in the TEC, perhaps due to the close proximity to the fallopian tube epithelium of the ovary and inflammatory factors released during ovulation. Further studies are needed to conclusively determine whether inflammation following ovulation causes DNA damage in the fallopian tube.

TECs are susceptible to DNA damage following ovulation, but the fate of the damaged cells is unknown. Although little or no apoptosis was observed in TEC following ovulation (data not shown), it is likely that some or all of the DNA damage is repaired. This may be reflected in a lack of increase in the percentage of TEC exhibiting H2A.X foci at $12 \mathrm{~h}$ posthCG compared with $16 \mathrm{~h}$ post-hCG, despite an increase in macrophage association with the TEC. It is possible that by $16 \mathrm{~h}$ after hCG treatment, TECs have begun to repair the double-strand DNA breaks observed following ovulation. Cells with unrepaired double-strand DNA breaks or DNA replication errors as a result of oxidative damage at critical sites, such as in tumor suppressor genes, may serve as progenitor cells for neoplastic lesions (Schildkraut et al. 2010). It is possible that the OSE, which undergoes cyclic remodeling during monthly ovulations, is better equipped to process cells damaged in response to ovulation compared to TEC. Investigation into the pathways necessary to repair DNA strand breaks may provide valuable information regarding the mechanisms of p53 protein regulation as part of the tubal 'precursor signature' and how mutations in BRCA increase the risk of high-grade serous cancer.

In summary, ovulation impacts the fallopian tube epithelium as well as the OSE, lending support to the correlation between a reduction in the number of lifetime ovulations and a reduced risk of ovarian cancer. Ovulation and its associated hormones did not increase proliferation or directly induce DNA lesions using novel organ culture systems and a newly generated tubal cell line. However, in vivo ovulation induced macrophage infiltration into the fallopian tube epithelium and enhanced DNA damage in the TEC similar to that observed with reactive oxidants in vitro. This study examines the three major hypotheses connecting a long-standing correlation between ovulation and the risk of ovarian cancer in light of emerging evidence suggesting that the fallopian tube epithelium may be a site of origin for serous carcinomas. 


\section{Supplementary data}

This is linked to the online version of the paper at http://dx. doi.org/10.1530/ERC-11-0107.

\section{Declaration of interest}

The authors declare that there is no conflict of interest that could be perceived as prejudicing the impartiality of the research reported.

\section{Funding}

This work was supported by BIRCWH grant K12HD055892, NIH grant R03CA139492, Ovarian Cancer Research Fund Liz Tilberis LT/UIC/01.2011, UIC Cancer Center Grant, and UIC Center for Clinical and Translational Science grant to J E Burdette. This research was supported by Eunice Kennedy Shriver NICHD/NIH grant 5U54HD040093-10 to A T Fazleabas as part of the Specialized Cooperative Centers Program in Reproduction and Infertility Research.

\section{Author contribution statement}

S M King carried out immunohistochemistry and immunofluorescence analyses, participated in chemically induced ovulation studies, carried out organ culture studies, performed western blot analyses and RT-PCR, and drafted the manuscript. T S Hilliard carried out MTS analyses and immunofluorescence analyses. L Y Wu participated in immunohistochemistry analyses. R C Jaffe performed luciferase analysis of TEC40 cells and critical reading of the manuscript. A T Fazleabas provided baboon tissue and critical reading and revision of the manuscript. J E Burdette conceived of the study design, participated in its design and coordination, and involved in manuscript preparation and revision. All authors read and approved the final manuscript.

\section{References}

Akkoyunlu G, Korgun ET, Celik-Ozenci C, Seval Y, Demir R \& Ustunel I 2003 Distribution patterns of leucocyte subpopulations expressing different cell markers in the cumulus-oocyte complexes of pregnant and pseudopregnant mice. Reproduction, Fertility, and Development 15 389-395. (doi:10.1071/RD03037)

Altekruse S, Kosary C, Krapcho M, Neyman N, Aminou R, Waldron W, Ruhl J, Howlader N, Tatalovich Z, Cho H, et al. 2010 SEER Cancer Statistics Review, 1975-2007. http://seer.cancer.gov/csr/1975_2007/. Based on Nov 2009 SEER data submission, posted online 2010. National Cancer Institute: Bethesda, MD, USA.

An Y, Liu K, Zhou Y \& Liu B 2009 Salicylate inhibits macrophage-secreted factors induced adipocyte inflammation and changes of adipokines in 3T3-L1 adipocytes. Inflammation 32 296-303. (doi:10.1007/s10753-0099135-1)
Auersperg N 2011 The origin of ovarian carcinomas: a unifying hypothesis. International Journal of Gynecological Pathology 30 12-21. (doi:10.1097/PGP. 0b013e3181f45f3e)

Auersperg N, Maines-Bandiera SL, Dyck HG \& Kruk PA 1994 Characterization of cultured human ovarian surface epithelial cells: phenotypic plasticity and premalignant changes. Laboratory Investigation 71 510-518.

Auersperg N, Maines-Bandiera SL \& Dyck HG 1997 Ovarian carcinogenesis and the biology of ovarian surface epithelium. Journal of Cellular Physiology 173 261-265. (doi:10.1002/(SICI)1097-4652(199711)173:2<261::AID -JCP32>3.0.CO;2-G)

Auersperg N, Ota T \& Mitchell GW 2002 Early events in ovarian epithelial carcinogenesis: progress and problems in experimental approaches. International Journal of Gynecological Cancer 12 691-703. (doi:10.1046/j.15251438.2002.01152.x)

Auersperg N, Woo MM \& Gilks CB 2008 The origin of ovarian carcinomas: a developmental view. Gynecologic Oncology 110 452-454. (doi:10.1016/j.ygyno.2008.05. 031)

Austyn JM \& Gordon S 1981 F4/80, a monoclonal antibody directed specifically against the mouse macrophage.

European Journal of Immunology 11 805-815. (doi:10. 1002/eji.1830111013)

Bartkova J, Horejsi Z, Koed K, Kramer A, Tort F, Zieger K, Guldberg P, Sehested M, Nesland JM, Lukas C et al. 2005 DNA damage response as a candidate anti-cancer barrier in early human tumorigenesis. Nature 434 864-870. (doi:10.1038/nature03482)

Bell DA 2005 Origins and molecular pathology of ovarian cancer. Modern Pathology 18 (Suppl 2) S19-S32. (doi:10. 1038/modpathol.3800306)

Burdette JE, Kurley SJ, Kilen SM, Mayo KE \& Woodruff TK 2006 Gonadotropin-induced superovulation drives ovarian surface epithelia proliferation in CD1 mice. Endocrinology 147 2338-2345. (doi:10.1210/en.20051629)

Cass I, Holschneider C, Datta N, Barbuto D, Walts AE \& Karlan BY 2005 BRCA-mutation-associated fallopian tube carcinoma: a distinct clinical phenotype? Obstetrics and Gynecology 106 1327-1334. (doi:10.1097/01.AOG. 0000187892.78392.3f)

Choi KC, Kang SK, Tai CJ, Auersperg N \& Leung PC 2002 Follicle-stimulating hormone activates mitogen-activated protein kinase in preneoplastic and neoplastic ovarian surface epithelial cells. Journal of Clinical Endocrinology and Metabolism 87 2245-2253. (doi:10.1210/jc.87.5. 2245)

Choi JH, Chen CL, Poon SL, Wang HS \& Leung PC 2009 Gonadotropin-stimulated epidermal growth factor receptor expression in human ovarian surface epithelial cells: involvement of cyclic AMP-dependent exchange protein activated by cAMP pathway. Endocrine-Related Cancer 16 179-188. (doi:10.1677/ERC-07-0238) 
Critoph FN \& Dennis KJ 1977 The cellular composition of the human oviduct epithelium. British Journal of Obstetrics and Gynaecology 84 219-221. (doi:10.1111/j.14710528.1977.tb12559.x)

Croteau DL \& Bohr VA 1997 Repair of oxidative damage to nuclear and mitochondrial DNA in mammalian cells. Journal of Biological Chemistry 272 25409-25412. (doi:10.1074/jbc.272.41.25409)

Crum CP, Drapkin R, Kindelberger D, Medeiros F, Miron A \& Lee Y $2007 a$ Lessons from BRCA: the tubal fimbria emerges as an origin for pelvic serous cancer. Clinical Medicine \& Research 535-44. (doi:10.3121/cmr.2007.702)

Crum CP, Drapkin R, Miron A, Ince TA, Muto M, Kindelberger DW \& Lee Y $2007 b$ The distal fallopian tube: a new model for pelvic serous carcinogenesis. Current Opinion in Obstetrics \& Gynecology 19 3-9. (doi:10.1097/GCO.0b013e328011a21f)

Fathalla MF 1971 Incessant ovulation - a factor in ovarian neoplasia? Lancet 2 163. (doi:10.1016/S01406736(71)92335-X)

Gaytan M, Morales C, Bellido C, Sanchez-Criado JE \& Gaytan F 2007 Macrophages in human fallopian tube and ovarian epithelial inclusion cysts. Journal of Reproductive Immunology 73 66-73. (doi:10.1016/j.jri. 2006.06.002)

Hakim AA, Barry CP, Barnes HJ, Anderson KE, Petitte J, Whitaker R, Lancaster JM, Wenham RM, Carver DK, Turbov $\mathrm{J}$ et al. 2009 Ovarian adenocarcinomas in the laying hen and women share similar alterations in p53, ras, and HER-2/neu. Cancer Prevention Research 2 114-121. (doi:10.1158/1940-6207.CAPR-08-0065)

Jabbour HN, Sales KJ, Catalano RD \& Norman JE 2009 Inflammatory pathways in female reproductive health and disease. Reproduction 138 903-919. (doi:10.1530/REP09-0247)

Jackson KS, Inoue K, Davis DA, Hilliard TS \& Burdette JE 2009 Three-dimensional ovarian organ culture as a tool to study normal ovarian surface epithelial wound repair. Endocrinology 150 3921-3926. (doi:10.1210/en.20081674)

Jaffe RC, Donnelly KM \& Fazleabas AT 2003 The induction of baboon glycodelin expression by progesterone is not through Sp1. Molecular Human Reproduction 9 35-40. (doi:10.1093/molehr/gag008)

Jarboe E, Folkins A, Nucci MR, Kindelberger D, Drapkin R, Miron A, Lee Y \& Crum CP 2008a Serous carcinogenesis in the fallopian tube: a descriptive classification. International Journal of Gynecological Pathology 27 1-9. (doi:10.1097/pgp.0b013e31814b191f)

Jarboe EA, Folkins AK, Drapkin R, Ince TA, Agoston ES \& Crum CP $2008 b$ Tubal and ovarian pathways to pelvic epithelial cancer: a pathological perspective. Histopathology 53 127-138. (doi:10.1111/j.1365-2559.2007. 02938.x)

Jemal A, Siegel R, Ward E, Hao Y, Xu J \& Thun MJ 2009 Cancer statistics, 2009. CA: A Cancer Journal for Clinicians 59 225-249. (doi:10.3322/caac.20006)
Karst AM, Levanon K \& Drapkin R 2011 Modeling high-grade serous ovarian carcinogenesis from the fallopian tube. PNAS 108 7547-7552. (doi:10.1073/pnas.1017300108)

King SM, Quartuccio S, Hilliard TS, Inoue K \& Burdette JE 2011 Alginate hydrogels for three-dimensional organ culture of ovaries and oviducts. Journal of Visualized Experiments 52 pii 2804. (doi:10.3791/2804)

Komatsu M \& Fujita H 1978 Electron-microscopic studies on the development and aging of the oviduct epithelium of mice. Anatomy and Embryology 152 243-259. (doi:10. 1007/BF00350523)

Konishi I, Kuroda H \& Mandai M 1999 Review: gonadotropins and development of ovarian cancer. Oncology 57 (Suppl 2) 45-48. (doi:10.1159/000055274)

Kurman RJ \& Shih Ie M 2010 The origin and pathogenesis of epithelial ovarian cancer: a proposed unifying theory. American Journal of Surgical Pathology 34 433-443. (doi:10.1097/PAS.0b013e3181cf3d79)

Lee Y, Miron A, Drapkin R, Nucci MR, Medeiros F, Saleemuddin A, Garber J, Birch C, Mou H, Gordon RW et al. 2007 A candidate precursor to serous carcinoma that originates in the distal fallopian tube. Journal of Pathology 211 26-35. (doi:10.1002/path.2091)

Levanon K, Ng V, Piao HY, Zhang Y, Chang MC, Roh MH, Kindelberger DW, Hirsch MS, Crum CP, Marto JA et al. 2010 Primary ex vivo cultures of human fallopian tube epithelium as a model for serous ovarian carcinogenesis. Oncogene 29 1103-1113. (doi:10.1038/onc.2009.402)

Murdoch WJ 2008 Ovulatory factor in ovarian carcinogenesis. Advances in Experimental Medicine and Biology 622 119-128. (doi:10.1007/978-0-387-68969-2)

Murdoch WJ, Townsend RS \& McDonnel AC 2001 Ovulation-induced DNA damage in ovarian surface epithelial cells of ewes: prospective regulatory mechanisms of repair/survival and apoptosis. Biology of Reproduction 65 1417-1424. (doi:10.1095/biolreprod65. 5.1417)

Ness RB, Cramer DW, Goodman MT, Kjaer SK, Mallin K, Mosgaard BJ, Purdie DM, Risch HA, Vergona R \& Wu AH 2002 Infertility, fertility drugs, and ovarian cancer: a pooled analysis of case-control studies. American Journal of Epidemiology 155 217-224. (doi:10.1093/aje/ 155.3.217)

Robinson-Smith TM, Isaacsohn I, Mercer CA, Zhou M, Van Rooijen N, Husseinzadeh N, McFarland-Mancini MM \& Drew AF 2007 Macrophages mediate inflammation-enhanced metastasis of ovarian tumors in mice. Cancer Research 67 5708-5716. (doi:10.1158/00085472.CAN-06-4375)

Sambrook J, Fritsch EF \& Maniatis T 1989 Molecular Cloning: A Laboratory Manual. Cold Spring Harbor: Cold Spring Harbor Press.

Schildkraut JM, Iversen ES, Wilson MA, Clyde MA, Moorman PG, Palmieri RT, Whitaker R, Bentley RC, Marks JR \& Berchuck A 2010 Association between DNA 
damage response and repair genes and risk of invasive serous ovarian cancer. PLoS ONE 5 e10061. (doi:10. 1371/journal.pone.0010061)

Scully RE 1995 Early de novo ovarian cancer and cancer developing in benign ovarian lesions. International Journal of Gynaecology and Obstetrics 49 (Suppl) S9-S15. (doi:10.1016/0020-7292(95)02404-Z)

Straub RH 2007 The complex role of estrogens in inflammation. Endocrine Reviews 28 521-574. (doi:10. 1210/er.2007-0001)

Symonds DA, Merchenthaler I \& Flaws JA 2008 Methoxychlor and estradiol induce oxidative stress DNA damage in the mouse ovarian surface epithelium. Toxicological Sciences 105 182-187. (doi:10.1093/ toxsci/kfn100)

Trevino LS, Giles JR, Wang W, Urick ME \& Johnson PA 2010 Gene expression profiling reveals differentially expressed genes in ovarian cancer of the hen: support for oviductal origin? Hormones \& Cancer 1 177-186. (doi:10.1007/s12672-010-0024-8)

Umezu T, Hanazono M, Aizawa S \& Tomooka Y 2003 Characterization of newly established clonal oviductal cell lines and differential hormonal regulation of gene expression. In Vitro Cellular \& Developmental Biology. Animal 39 146-156. (doi:10.1007/s11626-003-0009-9)

West-Farrell ER, Xu M, Gomberg MA, Chow YH, Woodruff TK \& Shea LD 2009 The mouse follicle microenvironment regulates antrum formation and steroid production: alterations in gene expression profiles. Biology of Reproduction $\mathbf{8 0}$ 432-439. (doi:10.1095/biolreprod.108.071142)

Xu M, West E, Shea LD \& Woodruff TK 2006 Identification of a stage-specific permissive in vitro culture environment for follicle growth and oocyte development. Biology of Reproduction 75 916-923. (doi:10.1095/biolreprod.106. 054833)

Zhang M, Shi H, Segaloff DL \& Van Voorhis BJ 2001 Expression and localization of luteinizing hormone receptor in the female mouse reproductive tract. Biology of Reproduction 64 179-187.

Zheng W, Magid MS, Kramer EE \& Chen YT 1996 Folliclestimulating hormone receptor is expressed in human ovarian surface epithelium and fallopian tube. American Journal of Pathology 148 47-53.

Zolti M, Ben-Rafael Z, Meirom R, Shemesh M, Bider D, Mashiach S \& Apte RN 1991 Cytokine involvement in oocytes and early embryos. Fertility and Sterility $\mathbf{5 6}$ 265-272.

Received in final form 8 July 2011

Accepted 3 August 2011

Made available online as an Accepted Preprint 3 August 2011 